DOI: $10.2478 /$ rpp-2018-0021

$\mathrm{PhD}$ in Psychology, Postdoctoral Researcher, NATALIIA SYSKO

The Institute for Pedagogical Education and Adult Education of The National Academy of Pedagogical Sciences of Ukraine, Ukraine Address: 9 M. Berlynskyi St., Kyiv, 04060, Ukraine E-mail: nnsysko@ukr.net

\title{
PROFESSIONAL DEVELOPMENT OF TEACHERS UNDER THE CONDITIONS LIFELONG LEARNING: FOREIGN EXPERIENCE
}

\begin{abstract}
The article analyzes foreign experience in continuing professional development of teachers. It has been found that the system of continuing professional development of teachers in foreign countries has its own conceptual peculiarities determined by relevant contextual factors. It has been specified that all systems are characterized by personalityoriented approach to professional development of teachers, available organizational and pedagogical conditions for development, flexibility, diversity of forms and training content. Such an approach can enhance professionalism of teachers, their ability to provide students with high-quality and effective teaching in accordance with the needs of a market economy. It has been outlined that professional development of teachers is the most effective at the level of an educational institution in the course of daily teaching activities, provided the forms of this process organization are diverse. The key factor, which influences effectiveness of continuing professional development is the teacher's ability to reflect, motivation, responsibility and academic mobility within professional development. It has been clarified that a number of countries apply national mechanisms for recognizing the results of teachers' professional development, their certification. We believe it necessary to creatively use foreign innovative experience to enhance continuing professional development of teachers in Ukraine, namely, to create a multi-level system of continuing professional development of vocational education teachers and introduce motivational mechanisms for stimulating their professional growth.
\end{abstract}

Keywords: continuing professional development, advanced training, teacher, competency, educational institution, foreign experience, concepts, systems.

\section{INTRODUCTION}

The present stage of human development is characterized by dynamic globalization processes, development of digital technologies and scientific production, which, in turn, determine changes in education systems that must be prepared to respond to the challenges timely and qualitatively and educate qualified specialists, who are competitive in the modern labour market.

The advanced paradigm of education development in Ukraine highlights the need to develop modern vocational education, which should provide high-quality training of specialists in accordance with innovative development of production and economy, ensure personalized realization of specialists' professional potential for life, taking into account their capabilities, needs, motivation, opportunities and experience. In order to realize the outlined objectives, it is necessary to solve the main task, namely, to create conditions for 
sciendo Порівняльна професійна педагогіка 8(2)/2018

Comparative Professional Pedagogy 8(2)/2018

continuing professional development of vocational education teachers, who are able to prepare modern competitive specialists.

The search for probable solutions to the problem of continuing professional development of vocational education teachers in the education system of Ukraine objectively determines relevance of this problem within global educational space.

\section{THE AIM OF THE STUDY}

The article aims to analyze positive experience in organizing continuing professional development of teachers in foreign countries, to define the conceptual principles and conditions of its practical introduction into the system of continuing professional development of professional (vocational) education teachers in Ukraine.

\section{THEORETICAL FRAMEWORK AND RESEARCH METHODS}

The development of lifelong learning for teachers has been paid much attention in researches by Ukrainian scholars (S. Honcharenko, V. Kremen, L. Lukianova, N. Nychalo, I. Ziaziun). The importance of studying foreign experience in education development has been highlighted by N. Abashkina, N. Avshenyuk, N. Bidyuk, L. Diachenko, O. Lokshyna, O. Ohienko, L. Puhovska et al. Comparative pedagogical researches on continuing professional development of teachers in the most developed countries have been conducted by O. Borodiienko, N. Kliasen, V. Kovalchuk, N. Kotelnikova, N. Mukan, N. Paziura, O. Shatska, S. Synenko, A. Turchyn et al. The problems of teachers' advanced training and professional growth have been investigated by such foreign scholars as G. Bereday, S. Day, A. Glatthorn, A. Hargreaves, E. Villegas-Reimers et al.

To achieve the aim of the research, foreign and Ukrainian scholars' works have been theoretically generalized.

\section{RESULTS}

On September 1, 2017, the Association Agreement between Ukraine and the European Union entered into force. In Chapter 23, "Education, training, and youth", this document proclaims the implementation of measures aimed at intensifying the exchange of information, practice and experience for closer cooperation in the field of vocational education and training with the aim of developing vocational education and training, advanced training during professional activity, which should correspond to the realities in the context of changes in the labour market; creating the national mechanisms in order to improve transparency and recognition of qualifications and competencies, using, where possible, EU experience (Article 432), exploring the possibilities for developing cooperation, in particular in the field of distance learning and lifelong learning (Article 433).

New conceptual principles of reforming vocational education in Ukraine, taking into account European experience and solving a number of tasks for its systematic modernization, require innovative educators, whose professional development is a continuing, dynamic and multilevel process. In particular, L. Lukianova (2015) indicates that "the constant acquisition of knowledge, methodologies and technologies is an absolute factor in supporting the appropriate qualification of specialists, which justifies the guiding principle of modern education - its continuity, which determines the strategic reference point for social progress".

L. Puhovska (2011) notes that "for Ukrainian comparativists, the problem of teacher professional development is rather new. It has been briefly considered in the context of teachers' advanced training. Under the conditions of Ukraine's integrating into European and global scientific spaces, it is necessary that comparative pedagogy as a scientific branch occupy the proper place among human sciences, and comparative studies 
on the problem of professional development become top-priority and be offered targeted support" (p. 105).

The overview of foreign researches shows that professional development of teachers is interpreted by scholars in different contexts.

A. Glatthorn (1995) conceptually considers this phenomenon as an increase in the teacher's professional achievements due to accumulation of practical experience and systematic analysis of their teaching. According to the author's conception, teacher professional development is considered as a broader concept than merely career development or staff development, since career development involves only "undergoing career stages", and staff development is conducted through "providing teachers with organized programmes for advanced training" (Glatthorn, 1995, p. 41). In addition, the scholar notes that professional development consists of both formal experience (professional development, mentoring, attending professional seminars, workshops, etc.) and informal experience (independent study of pedagogical editions, professional literature, video production) (Glatthorn, 1995, p. 41).

A. Hargreaves (1995) clarifies the concept of teacher professional development, emphasizing such its components as "moral goals of teaching, political awareness, acuteness and experience of teachers, devotion and responsibility for their work" (p. 126).

The English scholar S. Day (1999) indicates that professional development of teachers benefits not only the teacher themself, but their colleagues, educational institution in general and quality of learning in particular (p. 4).

E. Villegas-Reimers (2002), investigating a wide range of researches on professional development in the global context, outlined the promising characteristics of this phenomenon, identified by the well-known scholars: teachers are the subjects of active learning based on constructivism (L. Darling-Hammond, A. Lieberman); they are reflexive practitioners, acquire new competencies during pedagogical activity and require assistance in creating new pedagogical theories and practices (M. Cochran-Smith, S. Lytle); their professional development occurs during cooperation and interaction with other teachers, administration, parents, community (L. Darling-Hammond, M. Clement); the most effective form of teacher professional development is in-service training involving various forms of daily teaching activities (L. Darling-Hammond, M. King, F. Newman); professional development of teachers is inextricably linked with education reforms, development of a new pedagogical culture and social expectations of positive results from teaching activities (S. Loucks-Horsley); teacher professional development occurs during choosing optimally and combining different forms, methods, technologies of learning, which facilitate models of professional development, which are the most appropriate for a particular educational institution or situation (J. Scribner); professional development is a long-term process of teachers' lifelong learning (D. Cohen, T. Ganser) (pp. 13-15). It must be noted that the generalizations outlined in this research are still relevant and cause a great interest of the researchers who investigate this problem, transform its conclusions into new researches on teacher professional development, generating new paradigms and practices.

The substantive provisions for continuing professional development of teachers are outlined in "The International Handbook on the Continuing Professional Development of Teachers" by Ch. Day \& J. Sachs (2005), which has become authoritative in global scientific and pedagogical community. It describes several areas for advanced researches on continuing professional development of teachers. In particular, this relates to determining the influence of teachers' development on the learning process and learning outcomes. 
Sciendo Порівняльна професійна педагогіка 8(2)/2018

Comparative Professional Pedagogy 8(2)/2018

In order to evaluate effectiveness of any methodology in the context of continuing professional development of teachers, it is rather essential to address such issues as assessment of teachers' educational achievements, the very process of assessment, assessment economy, methods and needs in assessing teachers' educational achievements.

The next relevant aspect of the research is determined by the need to clarify significance and influence of both theory and practice on the results of continuing professional development of teachers, their correspondence.

The Bruges Communiqué (2010) invites EU Member States to invest in flexible systems of teacher training, as well as their professional development, which will enable them to master new professional and pedagogical competencies, apply new methods and tools in teaching, pedagogical and industrial technologies (The European Commission, 2010).

Comparing different countries' experience in their approaches to continuing professional development of teachers allows discovering patterns and principles of professional development of professional (vocational) education teachers in Ukraine taking into account the contextual factors of the country.

The analysis of researches on the study of the system of teacher training in the United States shows that the education policy in the country is aimed at adjusting pedagogical mastery of teachers to modern educational needs based on the continuity of teachers' general and professional development. In this regard, the country has continued to seek effective forms and methods of advanced training for teachers. In addition, various training programmes are regularly developed at the federal and regional levels (Shevchuk, 2001).

Taking into account the urgent need to bring professionalism of teachers to a qualitatively new level, the US Congress approved the national programme of teacher centers in 1975. It ensured allocating funds for their establishment in states and individual districts. Teacher centers were expected to provide teachers with educational services, so that they might independently choose programmes for advanced training based on their individual needs (Shevchuk, 2001).

In order to enhance teachers' motivation towards professional development, the National Commission on Excellence in Education in the Nation at Risk Report (1983) recommended developing so-called "career steps" that would identify the difference between novice teachers, experienced teachers and master teachers. In 1986, the so-called Holmes Group, which was organized to promote teacher education reforms, proposed to create a hierarchy of teachers' positions, taking into account the level of their professional activities. In 1987, the United States established the National Board for Professional Teaching Standards and specified the procedures for monitoring knowledge of teachers through examinations and tests, and monitoring pedagogical and technological skills and abilities based on teaching activities recorded. New approaches to assessing teachers were introduced in a number of states with a view to a more thorough, objective assessment of teaching activities quality. In the Carnegie Commission's report titled "A Nation Prepared: Teachers for the 21st Century", it is stated that teachers' salaries will depend on teaching quality, since it is rather crucial to the status of this profession (Shevchuk, 2001).

To achieve the highest pedagogical level, there are 8 positions: one must obtain a bachelor's degree, a master's degree, and then undergo another 6 stages in the process of continuing professional development, gradually obtaining 30 credits from the knowledge that is relevant to the teacher. In some cases, teacher training becomes mandatory, if there is an urgent need. Tuition fees are paid by teachers or sponsors themselves. However, 
teachers are motivated towards professional growth, as the results of teacher certification significantly increases their salaries (Shevchuk, 2001).

In the system of postgraduate education, continuing professional development of teachers is conducted through various forms, namely, short-term (of a week's or month's duration) courses at universities, colleges, scientific centers; additional training at higher education institutions in order to improve methodological mastery or fulfill the requirements related to career growth; seminars, conferences, pedagogical fairs, Saturday and Sunday seminars, presentations of the best practices; the system of individual and group grants for creative teachers; self-study activities; academic paid leave after 7 and 14 years of working; internships, including abroad (Shevchuk, 2001).

In the United States, the following forms of professional development and advanced training for teachers are the most common: working with coaches and mentors; participating in summer training camps, as well as conferences and seminars in educational and other institutions; creating working groups for solving important pedagogical issues.

So, the conceptual system of continuing professional development of teachers in the USA is aimed at promoting teachers' professional growth based on the principle of diversifying various institutions, forms and content of training in accordance with individual educational needs of teachers, as well as programmes for school development.

In China, methodological basis for continuing professional development of teachers consists in the interaction between course-based advanced training along with methodological events held in educational institutions and self-study activities of teachers (Kotelnikova, 2012).

Studying the system of postgraduate teacher education in China, N. Kotelnikova (2011) identifies the main ways of its development at the present stage, namely, ordering and structuring postgraduate teacher education; providing it with the necessary legal framework; supporting the concept of lifelong learning, continuity of initial and postgraduate teacher education; enhancing knowledge and skills of teachers during in-service training; applying modern information technologies.

It has been found that advanced training for teachers in China is conducted at higher education institutions of certain type, taking into account teacher qualifications, as well as in regional centers and institutes. The most common features of advanced training for teachers are diversification and flexibility of curricula (short-term programmes, leisure programmes, part-time courses, individual lessons), taking into account specificity of certain regions in order to meet the needs of the labour market (Paziura, 2008).

At the present stage of postgraduate teacher education development in China, interactive and distance learning is widely used. The National Plan for Creating the National Internet Alliance of Teacher Education, approved by the Ministry of Education of the People's Republic of China in 2003, significantly contributed to its dissemination. Based on the most efficient educational resources, the introduced system provides teachers with the opportunity to be trained through different forms of learning, namely, distance learning, full-time learning, self-study activities. In this case, the credit trasfer and accumulation system is used to take into account teachers' educational achievements during advanced training, as well as other forms of learning (Shatska, 2012).

Using the Internet Alliance contributes to implementing a large-scale, cost-effective project of effective postgraduate education for teachers based on modern technologies and various training programmes (Borevskaia, 2003).

In Great Britain, continuing professional development of teachers is aimed at developing individual strategies and styles of teaching. It can be of two types, namely, 
sciendo Порівняльна професійна педагогіка 8(2)/2018

Comparative Professional Pedagogy 8(2)/2018

advanced training based on higher education institutions and school-based in-service training. The training content is aimed at mastering new aspects in theory and practice of pedagogical activity, acquiring self-study skills. Short-term narrowly specialized courses are widely common. More than $60 \%$ of study time is allocated for practical classes in various forms. Advanced training for teachers is free of charge and should be included into an employment contract. In the country, there are special boards, which assess professionalism of teachers (Kovalchuk, 2015).

In Germany, the system of continuing professional development of teachers is characterized by management decentralization, vertical administrative and organizational differentiation at the level of each of the 16 lands. Vocational education teachers can also engage in continuing development, which is realized at five levels, namely, national, land, regional, school and individual (Turchyn, 2011). In federal lands, they implement different strategies for developing professionalism of teachers, in particular, in terms of training duration, requirements for training content, the main forms of learning. Flexible, mobile and dynamic forms of training, as well as practical training through mentoring, namely, "training with the master", ensure professional development of vocational education teachers and increase their professional and pedagogical competency in accordance with their individual needs.

The main features of postgraduate teacher education in France include applying personality-oriented approach to organizing professional development of teachers, enhancing their motivation towards professional growth, teaching through research, introducing innovations into the education process, fullfiling real needs of school and society, establishing new and prominent educational research institutes (Synenko, 2002).

The content of advanced training courses involves a large number of practical exercises: micro-teaching, project presentations, simulation exercises, role-playing games, using video films, telecommunication and information technologies during the education process, as well as a wide range of courses on pedagogy and psychology (Lashchykhina, 2009).

In France, they have introduced a standardized duration of all periods of professional development from the beginning of active professional life to retirement, which is paid from the budget funds or the enterprise's funds. It should amount to a total of one year, or 1200 hours, if advanced training takes place in the workplace (Andritsou, 2005). Continuing professional development of teachers in France is provided by postgraduate education institutions, universities and regional education centers (Kovalchuk, 2015).

In Canada, professional development of teachers is regulated at the state level and is provided by universities, education departments that manage development of the national education policy, regional education centers, school boards, volunteer teacher associations, teachers' unions, private providers of professional development services, whose activities are aimed at organizing advanced training within schools (Mukan, 2007).

According to Canadian legislation, each school develops an annual plan for professional development of teachers that takes into account the strategy of the educational institution in accordance with the national and regional education development policy. Based on the developed plan and the teaching quality standard in Canada, each teacher develops a plan for individual professional development (Council of Ministers of Education, Canada, \& Canadian Commission for UNESCO, 2001). It must be noted that professional development of teachers is funded by education authorities in Canadian provinces. School boards are responsible for expedient use of funds, in particular in order to diversify teacher training (Council of Ministers of Education Canada, 2012). 
The Canadian teachers' associations explore the problems of teacher professional development, develop and promote advanced training programmes, provide teachers with access to them. Each association has a committee for teacher professional development. In this country, methods and mechanisms for monitoring and assessing the results of teachers' continuing professional development have been introduced (Council of Ministers of Education, Canada, \& Canadian Commission for UNESCO, 2001).

In Finland, a multilevel system for continuing professional development of teachers has been introduced. It combines such components as the Advisory Board for Professional Development of Education Personnel, the Finnish National Board of Education, teacher education departments, higher education institutions and schools. Advanced training is characterized by various forms of interaction based on the credit transfer and accumulation system, in particular, learner-centered, many-stage, cooperative learning, as well as practical learning (OECD, 2011).

In this country, they organize two/three-day advanced training for teachers every month. It is an obligatory part of teachers' pedagogical activity, with pay. It must be noted that such a training is practice-oriented and includes visits to other educational institutions with the aim of familiarizing with the most efficient pedagogical experience, so that they may implement its positive aspects into their own pedagogical activity (OECD, 2011).

Specificity in ensuring continuing professional development of teachers in Finland consists in close cooperation between schools and higher education institutions in order to enrich pedagogical activity with theory and practice (Asunta, 2006).

O. Borodienko (2017), studying the system of vocational education and training in Israel, notes that the development of human capital is part of the strategy for the country's socioeconomic development (Israel 2020: Strategic Vision for Economic Development). This position is considered to be primary in the country. The strategy for education development is aimed at achieving this goal. The education system should ensure high quality of the education process, students' educational progress and complement the requirements of the labour market in relation to knowledge, skills, competencies, qualifications.

The national plan for education development provides for enhancing professionalism of teachers, as well as the prestige of the teaching profession. Among the peculiarities of the system of vocational education and training in this country, the scholar identifies independent centers for assessing education quality, teaching quality and the level of teachers' qualifications. Continuing professional development of teachers is provided by the network of advanced training (PISGA) (Borodienko, 2017).

\section{CONCLUSIONS}

So, it can be concluded that every country has its own system of continuing professional development of teachers. These systems differ in conceptual features, which are determined by specific contextual factors.

The common feature of all systems is personality-oriented approach to organizing professional development of teachers and, consequently, creating relevant organizational and pedagogical conditions for it; providing flexibility, diversity of forms and content of training in order to bring the level of teachers' professionalism to the ability to ensure quality and effectiveness of student learning in accordance with the needs of a market economy.

Professional development of teachers is considered to be the most effective provided that this process is organized in various forms at the level of an educational institution in the course of daily teaching. Thus, the key factor, which influences 
sciendo Порівняльна професійна педагогіка 8(2)/2018

Comparative Professional Pedagogy 8(2)/2018

effectiveness of continuing professional development, is the teacher's ability to reflect, motivation, responsibility and academic mobility within professional development.

In addition, a number of countries (the USA, Great Britain, Germany, Finland) have created national mechanisms for recognizing the results of teachers' professional development, their certification. Therefore, we believe it necessary to creatively use foreign innovative experience to enhance continuing professional development of teachers in Ukraine, namely, to create a multi-level system of continuing professional development of vocational education teachers and introduce motivational mechanisms for stimulating their professional growth.

Prospects for further researches are seen in studying the mechanisms of motivating teachers towards continuing professional development in foreign countries.

\section{REFERENCES}

1. Andritsou, M. (2005). La formation continue des professeus de langues étrangères. Le français dans le monde, 325, 25.

2. Asunta, T. (2006). Developments in teacher education in Finland: in-service education and training. Retrieved from http://www.pef.uni-lj.si/bologna/dokumenti/posvetasunta.pdf.

3. Borevskaia, N. E. (2003). Gosudarstvo i shkola: opyt Kitaia na poroge III tysiacheletiia. Moskva: Vostochnaia literatura.

4. Borodiienko, O. V. (2017). Rozvytok system profesiinoi osvity i navchannia: dosvid Izrailiu. Teoriia i metodyka profesiinoi osvity, 2, 46-48.

5. Council of Ministers of Education Canada. (2012). Adult learning and education. Canada progress report for the UNESCO Global Report on Adult Learning and Education (GRALE) and the end of the United Nations Literacy Decade. Retrieved from https://www.cmec.ca/Publications/Lists/Publications/Attachments/283/GRALE_EN.pdf.

6. Council of Ministers of Education, Canada, \& Canadian Commission for UNESCO. (2001). The development of education in Canada. Report of Canada. Retrieved from http://www.cmec.ca/Publications/Lists/Publications/Attachments/34/ice46devca.en.pdf.

7. Day, S. (1999). Developing teachers: the challenge of lifelong learning. London: Falmer Press.

8. Day, Ch., \& Sachs, J. (2005). The international handbook on the continuing professional development of teachers. Maidenhead: Open University Press.

9. Glatthorn, A. (1995). Teacher development: international encyclopedia of teaching and teacher education. London: Pergamon Press.

10. Hargreaves, A. (1995). Development and desire: a post-modern perspective: professional development in education: new paradigms and practices. New York, NY: Teachers Colleges Press.

11. Kovalchuk, V. (2015). Profesiinyi rozvytok uchyteliv: zarubizhnyi dosvid. Vziato z http://education-ua.org/ua/porivnyalna-pedagogika/485-profesijnij-rozvitok-uchitelivzarubizhnij-dosvid.

12. Kotelnikova, N. (2011). Periodyzatsiia istorii rozvytku pisliadyplomnoi pedahohichnoi osvity v KNR. Istoryko-pedahohichnyi almanakh, 2, 77-82.

13. Kotelnikova, N. M. (2012). Systema pisliadyplomnoi osvity vchyteliv u Kytai. (Dys. kand. ped. nauk). Luhanskyi natsionalnyi universyteti meni Tarasa Shevchenka, Luhansk. 
14. Lashchykhina, V. P. (2009). Rozvytok systemy pidhotovky pedahohichnykh kadriv u Frantsii (druha polovyna XX - pochatok XXI stolittia). (Dys. kand. ped. nauk). Kyivskyi natsionalnyi linhvistychnyi universytet, Kyiv.

15. Lukianova, L. (2015). Neperervna osvita vprodovzh zhyttia: istorychnyi ohliad, suchasni realii. Naukovyi visnyk Melitopolskoho derzhavnoho pedahohichnoho universytetu. Seriia: Pedahohika, 2, 187-192.

16. Mukan, N. (2007). Systema neperervnoi profesiinoi osvity pedahohiv Kanady: instytutsii ta yikhnia diialnist. Visnyk Lvivskoho universytetu. Seriia: pedahohichna, 22, 227-231.

17. OECD. (2011). Lessons from PISA for the United States, strong performers and successful reformers in education. Retrieved from http://dx.doi.org/10.1787/ 9789264096660-en.

18. Paziura, N. V. (2008). Osoblyvosti rozvytku profesiino-tekhnichnoi osvity v Kytai (ostannia chvert XX stolittia). (Dys. kand. ped. nauk). Instytut pedahohichnoi osvity i osvity doroslykh APN Ukrainy, Kyiv.

19. Pukhovska, L. (2011). Profesiinyi rozvytok pedahohiv u hlobalnomu osvitnomu prostori. Porivnialna profesiina pedahohika, 1, 97-106.

20. Shatska, O. P. (2012). Rozvytok vyshchoi pedahohichnoi osvity v Kytai (70-ti rr. XX - pochatok XXI stolittia). (Dys. kand. ped. nauk). Luhanskyi natsionalnyi universyteti meni Tarasa Shevchenka, Luhansk.

21. Shevchuk, L. I. (2001). Udoskonalennia profesiinoi kompetentnosti pedahohiv yak vazhlyvyi chynnyk efektyvnosti navchalno-vykhovnoho protsesu v PTNZ. Profesiina osvita. Naukovo-metodychnyi visnyk, 1-2 (18-19), 3-18.

22. Synenko, S. I. (2002). Rozvytok pisliadyplomnoi pedahohichnoi osvity $v$ krainakh Zakhidnoi Yevropy (Anhliia, Frantsiia, Nimechchyna). (Avtoref. dys. kand. ped. nauk). Tsentralnyi instytut pisliadyplomnoi pedahohichnoi osvity APN Ukrainy, Kyiv.

23. The European Commission. (2010). The Bruges Communiqué on enhanced European Cooperation in Vocational Education and Training for the period 2011-2020. Retrieved from http://ec.europa.eu/dgs/education_culture/repository/education/policy/ vocational-policy/doc/brugescom en.pdf.

24. Turchyn, A. I. (2011). Systema pisliadyplomnoi osvity pedahohichnykh kadriv profesiino-osvitnikh zakladiv Nimechchyny. Zbirnyk naukovykh prats Khmelnytskoho instytutu sotsialnykh tekhnolohii Universytetu "Ukraina", 3, 173-180.

25. Villegas-Reimers, E. (2002). Teacher professional development: an international review of the literature. Paris: UNESCO, International Institute for Educational Planning. 